\title{
Paleogene opening of Drake Passage
}

\author{
Roy Livermore ${ }^{\mathrm{a}, *}$, Adrian Nankivell ${ }^{\mathrm{a}}$, Graeme Eagles ${ }^{\mathrm{b}}$, Peter Morris ${ }^{\mathrm{a}}$ \\ ${ }^{a}$ British Antarctic Survey, High Cross, Madingley Road, Cambridge, CB3 OET, United Kingdom \\ ${ }^{\mathrm{b}}$ Alfred Wegener Institute for Polar and Marine Research, Bremerhaven, Germany
}

Received 2 December 2004; received in revised form 3 March 2005; accepted 24 March 2005

Available online 5 July 2005

Editor: R.D. van der Hilst

\begin{abstract}
The timing of events leading to the earliest connection between the Pacific and Atlantic oceans at Drake Passage is controversial but important, because gateway opening probably had a profound effect on global circulation and climate. A rigorous new analysis of marine geophysical data demonstrates a major change in the motion of the South American and Antarctic plates at about $50 \mathrm{Ma}$, from N-S to WNW-ESE, accompanied by an eightfold increase in separation rate. This would have led to crustal extension and thinning, and perhaps the opening of small oceanic basins, with the probable formation of a shallow $(<1000 \mathrm{~m})$ gateway during the Middle Eocene. No change in South American-Antarctic motion is observed near the Eocene-Oligocene boundary, but a deep-water connection developed between 34 and 30 Ma, when continued extension led to the initiation of seafloor spreading at the West Scotia Ridge. These timings correlate with events seen in the oxygen isotope record from benthic foraminera, and support the view that Drake Passage opening was the trigger for abrupt Eocene-Oligocene climate deterioration and the growth of extensive Antarctic ice sheets.
\end{abstract}

(C) 2005 Elsevier B.V. All rights reserved.

Keywords: Gateways; Drake Passage; Plate kinematics; Cenozoic climate

\section{Global cooling and Southern Ocean gateways}

The Cenozoic $\delta^{18} \mathrm{O}$ record from benthic foraminera [1] shows a gradual decline in global temperature from about $50 \mathrm{Ma}$ (Early Eocene),followed, at 33-34 Ma (Eocene-Oligocene boundary), by an abrupt cooling/glaciation event (Oi-1), and then a

\footnotetext{
* Corresponding author.

E-mail address: ral@bas.ac.uk (R. Livermore).
}

prolonged cold period until $26 \mathrm{Ma}$, during which extensive ice sheets formed on East Antarctica. Formation of deep water 'gateways' at the South Tasman Rise and Drake Passage has long been recognized as a possible cause of the abrupt Eocene-Oligocene event, by creating a deep pathway for the Antarctic Circumpolar Current (ACC) and bringing about the thermal isolation of Antarctica $[2,3]$, although other models involving declining $\mathrm{CO}_{2}[4,5]$, closure of a circum-equatorial seaway [6] and tectonic uplift [7], have also been proposed. 
An influential theory suggesting that, even after ocean crust started to form in Drake Passage, the developing gateway might have been obstructed by relict continental crust until the Early Miocene (23.5 Ma or later, $[3,8])$, is unsupported by recent work [9]. Hence, correlation of earlier events in Drake Passage with the $\delta^{18} \mathrm{O}$ record would constitute strong evidence of a causal relationship between gateway opening and global changes in circulation and climate. Although it has been established $[8,10]$ that seafloor spreading occurred prior to magnetic chron C8 (26 Ma), and, probably, chron C10 (29 Ma), based on identification of anomalies within $100 \mathrm{~km}$ of the South American margin and in the southwest Scotia Sea [11], the kinematics and timing of the initial opening have remained obscure.

\section{South America-Antarctica plate tectonics}

The ultimate control on Drake Passage opening was the relative motion of the South American and Antarctic plates, which enclose the Scotia Sea. A detailed record of this motion is contained in remarkable sets of gravity and magnetic anomalies in the Weddell Sea (Fig. 1), formed as a consequence of seafloor spreading on the southern flank of the South American-Antarctic (SAM-ANT) plate boundary [12]. These data cannot be used in conventional methods for estimating plate motions, because much of the opposing, South American, flank of the spreading system has been lost by subduction beneath the Scotia Sea. Hence, the only rotations published to date for SAM-ANT motion are based on fitting of anomalies on the flanks of the South American-Antarctic Ridge [13], more than $1000 \mathrm{~km}$ east of Drake Passage, or else are derived by addition of rotations around the circuit: South America-Africa-Antarctica (e.g. [14]).

We have therefore extended the technique of Shaw and Cande [15], involving joint inversion of sea floor isochrons, derived from picks of magnetic anomalies, together with continuous flow lines derived from satellite gravity anomalies, to permit the inclusion of data from only one flank of a spreading segment. This 'non-conjugate' fitting involves matching each isochron with every other isochron on the same flank (Fig. 2), as was done by Engebretson et al. [16], using a different technique. To ensure that the overall con- tribution of a pick involved in non-conjugate fitting was no greater than a pick used for conjugate fitting, a weight was applied, equal to the inverse of the number of isochrons to which the pick was rotated. An iterative inversion procedure was then adopted to find the best-fitting model in a least-squares sense. The advantages of this technique are: i. solutions are constrained by continuous flow lines rather than by matching discrete azimuths, resulting in a much smoother migration of stage poles [17], ii. estimates of uncertainties and data importances (the contribution of individual data points to the solution) are provided by the inversion, iii. statistical analysis of results can be performed to ensure that assumptions about the distribution of errors are fulfilled.

We applied this technique to a data set consisting of picks ${ }^{1}$ of magnetic anomalies C6 (19 Ma), C8 (26 Ma), C13 (33 Ma), C18 (38 Ma), C20 (43 Ma), C21 (46 Ma), and $\mathrm{C} 30$ (66 Ma), from the compilation by Livermore and Woollett [12], augmented by additional picks from the southwest Atlantic (Fig. 3). These were combined with flow lines digitized from the satellite free-air gravity anomaly field [18], and inverted to produce a set of finite rotations describing South American motion with respect to Antarctica (Table 1), together with associated uncertainties.

\section{Results}

The set of solution poles and their uncertainty ellipses are plotted in Fig. 4, from which the smooth variation in pole location prior to $\mathrm{C} 8 \mathrm{y}$ is apparent. The westward jump at C30-C21 reflects the formation of the kink in the Weddell Sea flow lines, while the large southward jump at C8-C6 correlates with the abrupt change in plate motion that led to the formation of long-offset fracture zones on the South AmericanAntarctic Ridge [13,19]. Uncertainty ellipses are elongated in a direction approximately perpendicular to the flow lines, reflecting the relatively short length of ridge available, while the small uncertainty in the $\mathrm{W}-$ E direction results from the very good isochron fits obtained. Poles younger than C6 could not be esti-

\footnotetext{
${ }^{1}$ The younger end of the normal polarity chron is picked in each case.
} 

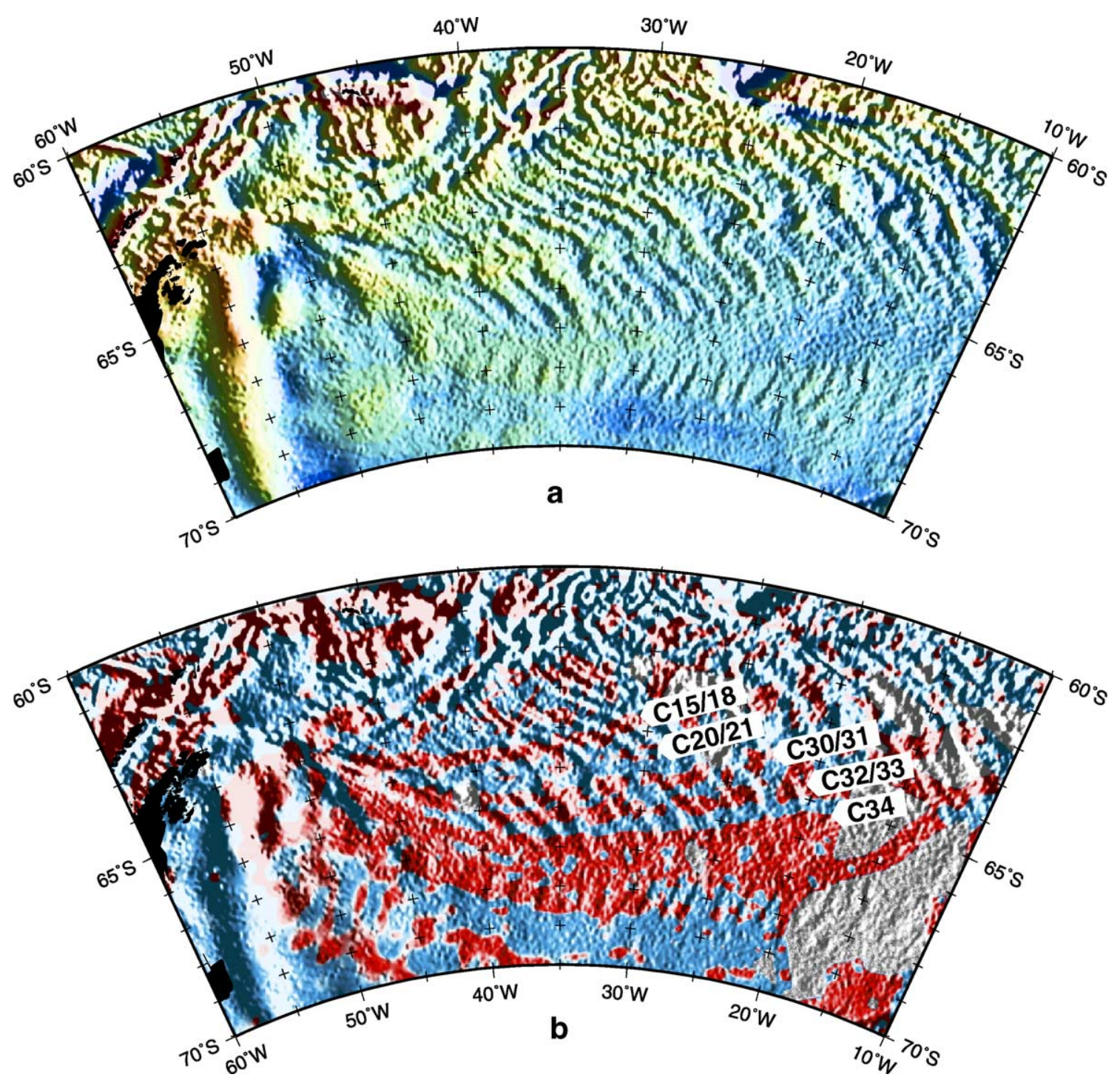

Fig. 1. a. Free-air gravity anomaly map of the Weddell Sea. Free-air gravity anomalies are taken from the 1-degree grid of Sandwell and Smith [19], version 11, and are shown as shaded relief (illuminated from the east). b. Magnetic anomalies from the ADMAP compilation [32], draped over the free-air gravity anomaly surface. Positive anomalies are shown in red and negative anomalies in blue; areas without data are shown as grey. Clearly identifiable and continuous anomalies are labelled.

mated with precision, because of the absence of more recent anomalies in the Weddell Sea, although the very good agreement of our C6 pole with the NUVEL-1A pole for SAM-ANT [20] strongly suggests that motion has been stable for the past $20 \mathrm{Ma}$.

Data importances are plotted in Fig. 3. Magnetic isochron importances are largest for the limited amount of data east of the South American-Antarctic
Ridge (Fig. 3a), while flow lines on the Antarctic flank which lack conjugates have slightly larger importances than data elsewhere (Fig. 3b). In wellsampled areas, such as the western Weddell Sea and western flank of the South American-Antarctic Ridge, importances are small, indicating a high degree of internal consistency. Accurate estimation of uncertainty in the inversion is dependent upon the 


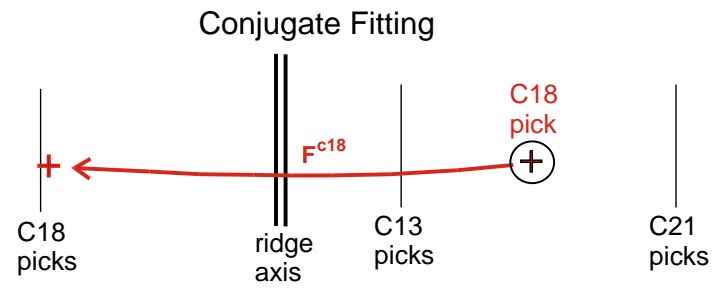

Non-conjugate Fitting

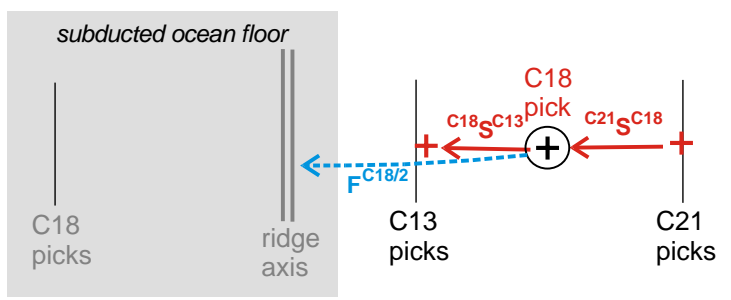

Fig. 2. Principle of non-conjugate fitting employed here. Top: in normal fitting, pick of anomaly, e.g. C18, is rotated to opposite flank of ridge, and matched to a great circle fitted to $\mathrm{C} 18$ picks in the same spreading compartment by varying the finite rotation $\mathbf{F}^{\mathrm{C} 18}$. Bottom: in 'non-conjugate' (e.g. where one flank, shaded grey here, is missing) fitting adopted here for the Weddell Sea data, pick of C18 is rotated to other isochrons on the same flank by varying stage rotations, e.g. $\mathbf{S}^{\mathrm{C} 18 / \mathrm{C} 21}$ (half-angle stage rotation for $\mathrm{C} 18$ to $\mathrm{C} 21$ ) and to the ridge axis, if it exists, by varying ridge rotations, e.g. $\mathbf{F}^{\mathrm{C} 18 / 2}$ (half the finite rotation for C18).

assumption of a Gaussian distribution of errors in the data. This assumption was tested by plotting the quantiles of the calculated errors against the quantiles of the theoretical (Gaussian) distribution. Such quantile-quantile plots approximate a straight line near the origin, deviating when outliers become apparent. In the case of our inversion, we plot the $10 \%$ quantiles for magnetic isochron and fracture zone (flow line) fits (Fig. 3c).

The results are compatible with spreading on a two-plate system, and show three phases of motion since the Late Cretaceous. Phase I began near chron C30 (66 Ma), and ended some time before chron C21 (46 Ma), and was a period of extremely slow SAM-
ANT separation in a $\mathrm{N}-\mathrm{S}$ direction, giving rise to minimal motion between the tips of Tierra del Fuego and the Antarctic Peninsula (Fig. 5). Phase II followed the abrupt change in direction from N-S to WNW-ESE near C21, accompanied by an increase in rate from $\sim 3$ to $\sim 24 \mathrm{~km} / \mathrm{Ma}$. Phase III commenced at about chron C6 (20 Ma), and marked a change to WE motion reported previously [13]. This probably led to a major reorganization within the Scotia Sea, involving the initiation of spreading at the East Scotia Ridge [21].

The phase I/II transition is marked by the bend at the northern end of the kink in Weddell Sea flow lines, observed by Livermore and Woollett [12]. This actually occurs to the south of $\mathrm{C} 21$, and is therefore somewhat older, probably $\sim 50 \mathrm{Ma}$, although it is not calibrated by a prominent magnetic anomaly (Fig. 1). This means that our stage pole progression is slightly smoothed, and our estimates of spreading rates within the kink tend to be slight overestimates. An increase in the rate of SAM-ANT motion, coupled with a change in direction, was reported by Cunningham et al. [14] for the interval 55 to $40 \mathrm{Ma}$, based on addition of SAM-AFR and AFR-ANT rotations. Their results did not resolve the kink in SAM-ANT flow lines, but indicated that a substantial W-E component of relative motion was maintained throughout this interval. We attribute this difference to a lack of resolution in the dating and definition of the changes observed at the southern Mid-Atlantic Ridge and Southwest Indian Ridge.

We speculate that the phase I/II change may have been associated with the initiation of subduction of South American ocean floor at a subduction zone east of South Orkney, which was then located near the tip of the Antarctic Peninsula (Fig. 5). Eastward retreat of this subduction zone was accompanied by extension and rifting of continental fragments formerly located near the junction between the tips of Tierra del Fuego and the Antarctic Peninsula. It is possible that the

Fig. 3. a. Distribution and data importances of magnetic anomaly picks (symbols) in the Weddell Sea and Southwest Atlantic. Magnetic chrons are labelled according to the nomenclature of Cande and Kent [33] (see key at top of figure). Radii of circles are proportional to data importances. b. Distribution and data importances of fracture zone locations used in the inversion. Fracture zone picks are indicated by small rectangular dots. c. Quantile-quantile (q-q) plots for the residuals for each type of data used in the inversion. The straight line represents the best-fit by linear regression for the central $\pm 1 \sigma$ of a Gaussian distribution. 
C1 C2A C5y C6y C8y C13y C18y C20y C21y C30y C32y C33y C33R C34y
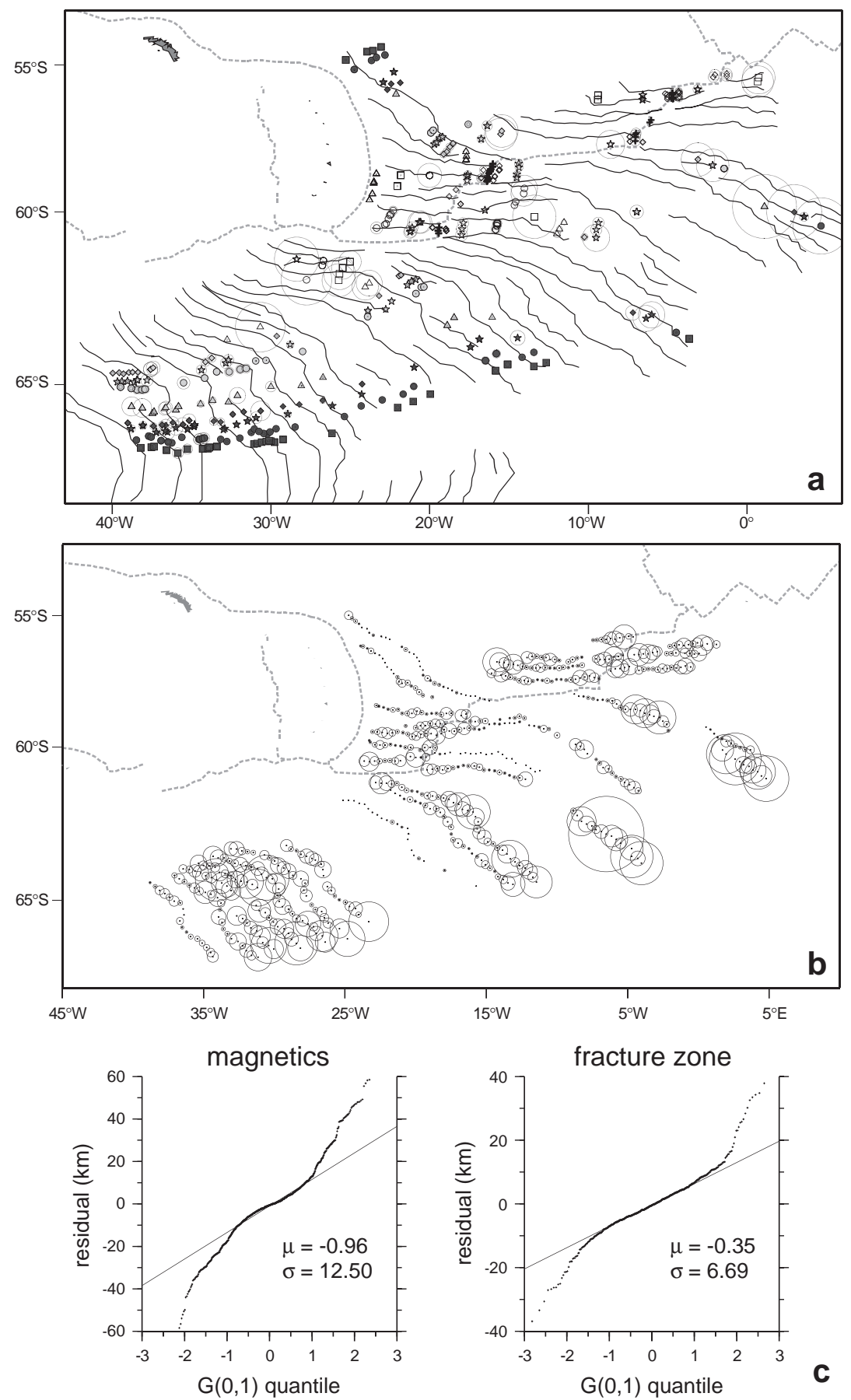

C 
Table 1

Total reconstruction rotations for South America with respect to Antarctica

\begin{tabular}{|c|c|c|c|c|c|c|c|c|}
\hline \multirow[t]{2}{*}{ Chron } & \multirow{2}{*}{$\begin{array}{l}\text { Age } \\
\text { (Ma) }\end{array}$} & \multirow{2}{*}{$\begin{array}{l}\text { Lat } \\
\left({ }^{\circ} \mathrm{N}\right)\end{array}$} & \multirow{2}{*}{$\begin{array}{l}\text { Lon } \\
\left({ }^{\circ} \mathrm{E}\right)\end{array}$} & \multirow{2}{*}{$\begin{array}{l}\text { Angle } \\
\left({ }^{\circ} \mathrm{acw}\right)\end{array}$} & \multicolumn{4}{|c|}{$95 \%$ confidence ellipsoid } \\
\hline & & & & & Axis 1 & Axis 2 & Axis 3 & Azimuth \\
\hline C6 & 19.05 & -85.88 & 146.44 & -6.79 & 1.31 & 0.16 & 0.04 & 107.86 \\
\hline $\mathrm{C} 8$ & 25.82 & -73.48 & 165.27 & -7.35 & 1.25 & 0.16 & 0.05 & 89.16 \\
\hline C13 & 33.06 & -75.11 & 172.61 & -10.26 & 0.97 & 0.12 & 0.04 & 80.13 \\
\hline C18 & 38.43 & -75.85 & 179.21 & -12.46 & 0.64 & 0.11 & 0.05 & 70.10 \\
\hline $\mathrm{C} 20$ & 42.54 & -77.15 & 187.47 & -14.02 & 0.57 & 0.10 & 0.05 & 64.53 \\
\hline $\mathrm{C} 21$ & 46.26 & -79.02 & 198.47 & -16.42 & 0.51 & 0.11 & 0.05 & 53.02 \\
\hline C30 & 65.58 & -78.43 & 225.32 & -19.31 & 0.55 & 0.09 & 0.06 & 34.29 \\
\hline
\end{tabular}

Axis measurements describing the $95 \%$ confidence ellipsoid in 3D space are in great circle degrees/2.79. Azimuth is that of axis 1 , measured counterclockwise from east.

occurrence of alkali basalts in the southern Powell Basin, dated at $47-50 \mathrm{Ma}[22]$, may be related to the initial stages of this subduction.

The low rate and N-S direction of SAM-ANT motion during phase I may reflect a temporary 'locking' of the plates in the region of the cusp between $\sim 66$ and $\sim 50 \mathrm{Ma}$ [12], causing South America to 'pivot' about a nearby SAM-ANT stage pole. With the initiation of subduction, westward motion of South America was no longer inhibited, and WNWESE motion was re-established. Such a large and abrupt change would have had major consequences, and might be expected to have led to the opening of the gateway. However, the timing of this change is much earlier than previous suggestions for Drake Passage opening $[3,6]$.

Evaluating uncertainties associated with these calculations is complicated [23], but we estimate errors to be $<10^{\circ}$ in direction, and $<5 \mathrm{~km} / \mathrm{Ma}$ in rate, i.e. much less than the changes observed at $\sim 50 \mathrm{Ma}$ and $\sim 20$ Ma. Uncertainties in timing of changes result from the absence of distinctive anomalies at crucial times, mis-identification of anomalies, and errors in the magnetic reversal timescale.

\section{Comparison with the spreading record in the Scotia Sea}

The ocean floor in Drake Passage was not formed by SAM-ANT spreading, as in the Weddell Sea, but was created at the West Scotia Ridge, which was isolated from the major plates during much of the Neogene by additional boundaries corresponding to the North Scotia Ridge and South Scotia Ridge [10]. The oldest confidently identified magnetic anomaly is C8 (26 Ma), which lies about $100 \mathrm{~km}$ from the South American passive margin on the northern flank (Fig. 6), except near the Shackleton Fracture Zone, where it abuts the continental slope. On the southern flank, a conjugate passive margin is not seen, having most probably been deformed and modified by strike-slip tectonics during the recent history of the South Scotia Ridge. Nevertheless, anomaly C8 has been identified on a small number of profiles, lying $100-150 \mathrm{~km}$ from the South Scotia Ridge $[8,11]$. Recent joint inversion of West Scotia Ridge data [10] has provided precise estimates of the rotations describing plate motions responsible for this spreading, together with their uncertainties. This model gives spreading rates of $20-25 \mathrm{~km} / \mathrm{Ma}$ for the phase of opening between $\mathrm{C} 8$ and C6B (26-23 $\mathrm{Ma})$. Extrapolation of these rates produces an estimate of $30 \mathrm{Ma}$ (chron C11) for the oldest deep-sea floor at the foot of the continental slope (Fig. 6). If earliest rates were slower, as is frequently the case following continental separation, then, of course, this age estimate would be slightly greater. For example, if rates prior to $\mathrm{C} 8$ were only half those between $\mathrm{C} 8$ and C6B, the age of the oldest crust would be $34 \mathrm{Ma}$ (chron C13). Hence, our best estimate of the age of the oldest crust in Drake Passage is $32 \pm 2 \mathrm{Ma}$, and onset of spreading as early as the Eocene-Oligocene boundary $(33.7 \mathrm{Ma})$ is a genuine possibility. The absence of anomalies $\mathrm{C} 13$ to $\mathrm{C} 11$, and the elusive nature of $\mathrm{C} 10$ could be explained by a predominantly tectonic mode of spreading, as suggested for the early stages of spreading elsewhere (e.g., [24]) or by 


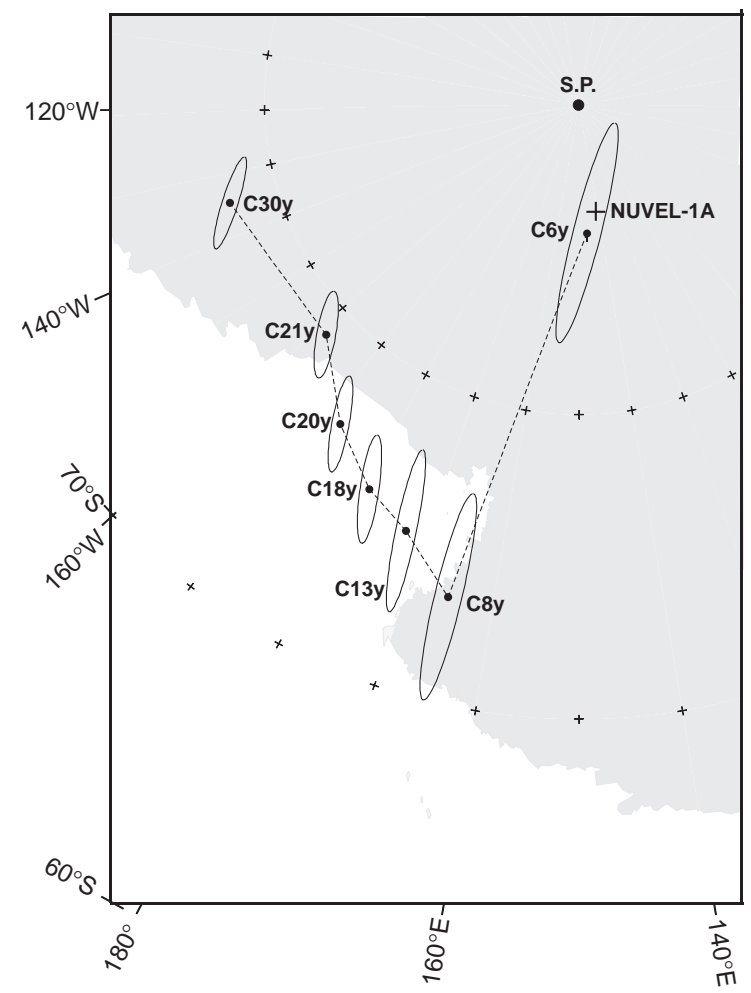

Fig. 4. Set of solution rotation poles and $95 \%$ uncertainty ellipses obtained for the inversion for SAM-ANT motion. The suffix ' $y$ ' denotes the younger end of the normal polarity chron. The NUVEL1A instantaneous pole for SAM-ANT [21] is shown for comparison with the C6y pole (see text).

an enhanced supply of sediments from the adjacent continents (e.g., [25]) during the earliest stages of opening. In the former case, we would expect oceanic basement to become rougher landward of $\mathrm{C} 8$, while the latter requires that erosion caused by any proto-ACC was insufficient to prevent sediment accumulation at the ridge axis.

\section{Eocene opening}

Our rotations suggest that a total of $278 \mathrm{~km}$ of WNW-ESE extension occurred in the region of the SAM-ANT cusp between 50 and $33 \mathrm{Ma}$, compared with only $57 \mathrm{~km}$ of N-S motion during phase I (66$50 \mathrm{Ma})$. This was most likely expressed as crustal faulting and subsidence, resulting in much of the thinned crust now dispersed in the Scotia Sea, such as Bruce Bank, Pirie Bank, and the South Orkney microcontinent. It is possible that this extension included rifting and localised seafloor spreading in a number of small basins within the Scotia Sea, such as the Protector Basin and Dove Basin (Fig. 6), which contain oceanic basement at depths consistent with an Eocene age [10].

Whether or not these basins were opening during the Eocene, it is likely that extension caused by plate separation led to the establishment of a marine connection between the Pacific and Atlantic across the broad, subsided continental shelves produced by Eocene stretching. The precise pathways and flow of deep currents through the early gateway depended then, as now, upon bathymetry created by tectonic processes. For example, fracture zones associated with the movement of crustal fragments such as South Georgia may have provided exit routes for deep currents, comparable to the 'Shag Rocks' and 'Georgia' passages, which today control flow through the Scotia Arc [26]. Likewise, any volcanic arc associated with the early subduction zone shown in Fig. 5 may have presented an additional barrier to flow, while the nearby trench provided a conduit for deep currents.

Although mainly shallow $(<1000 \mathrm{~m})$, the early seaway may have contributed to a decline in global temperatures through the Middle Eocene, as recorded in oxygen isotopes from benthic foraminifera (Fig. 7). Continued extension at the higher rates of phase II led eventually to a transition to full ocean spreading and the establishment of the West Scotia Ridge spreading centre at 34-30 Ma, creating the first deep connection through Drake Passage. The location of anomaly C8 near the foot of the continental slope in segment W1 (Fig. 6) could indicate a delay between the onset of spreading and the formation of a deep-water $(>2000 \mathrm{~m})$ gateway. However, C8 on the SE flank is separated from the South Scotia Ridge by about $150 \mathrm{~km}$ of deep water, suggesting that spreading had, indeed, begun on segment W1 well before $26 \mathrm{Ma}$. Possible explanations for the absence of deep water landward of $\mathrm{C} 8$ on the northwestern flank include ridge jumps and progradation of the margin. We therefore correlate the formation of a deep gateway by spreading at the West Scotia Ridge tentatively with the abrupt cooling event at the Eocene-Oligocene boundary (Fig. 


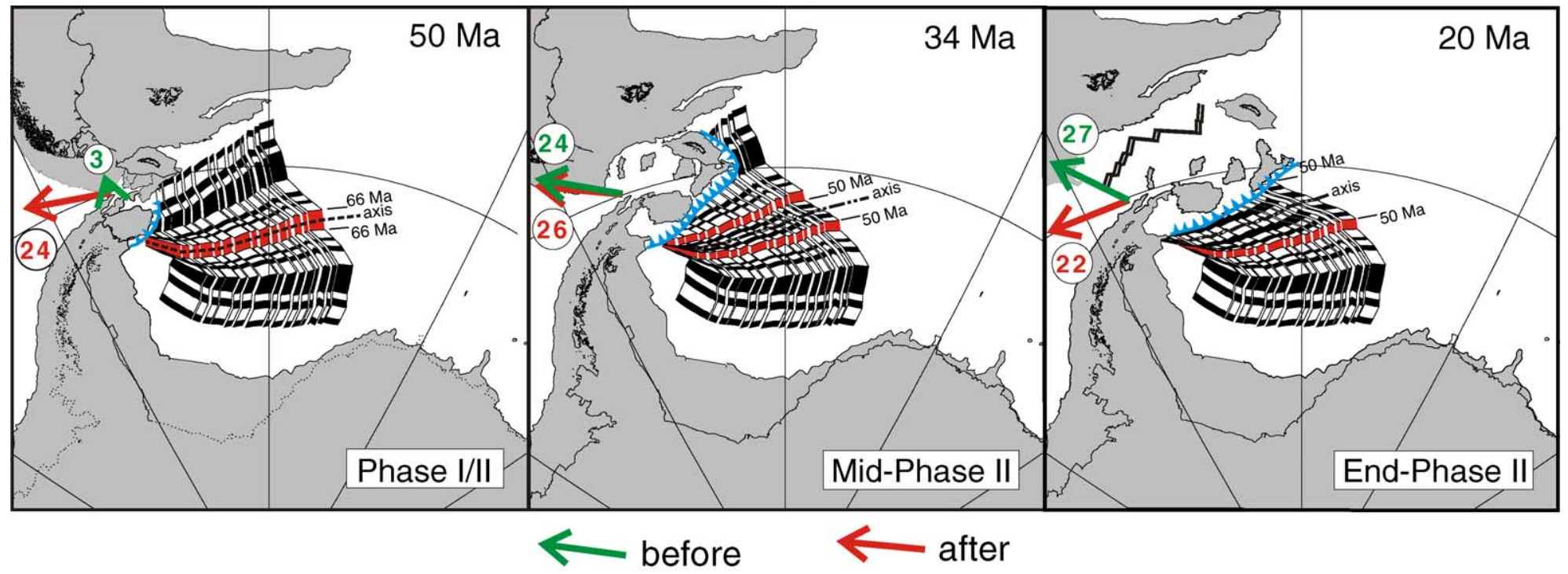

Fig. 5. Reconstructions of South America and Antarctica using the new parameters at i. $50 \mathrm{Ma}$, the proposed time of shallow ( $<1000 \mathrm{~m})$ Drake Passage opening, ii. $34 \mathrm{Ma}$, the earliest time at which a deep $(>2000 \mathrm{~m}$ ) connection was made by spreading at the West Scotia Ridge, and iii. $20 \mathrm{Ma}$, when a major change in SAM-ANT motion occurred. A gap opens between the tips of Tierra del Fuego and the Antarctic Peninsula between 50 and $34 \mathrm{Ma}$, although this takes no account of internal deformation of the plates. Plate motion vectors for SAM-ANT are shown for a point $\left(60^{\circ} \mathrm{S}, 57^{\circ} \mathrm{W}\right.$ fixed to Antarctica) in the Drake Passage. Motion immediately prior to the map age is shown in green, that immediately after in red. Synthetic flow lines and isochrons are shown, based on the new rotations, for both flanks of the spreading centre, although much of the northern flank was subsequently lost by subduction beneath the growing Scotia Sea (blue lines with teeth define subduction zone). 


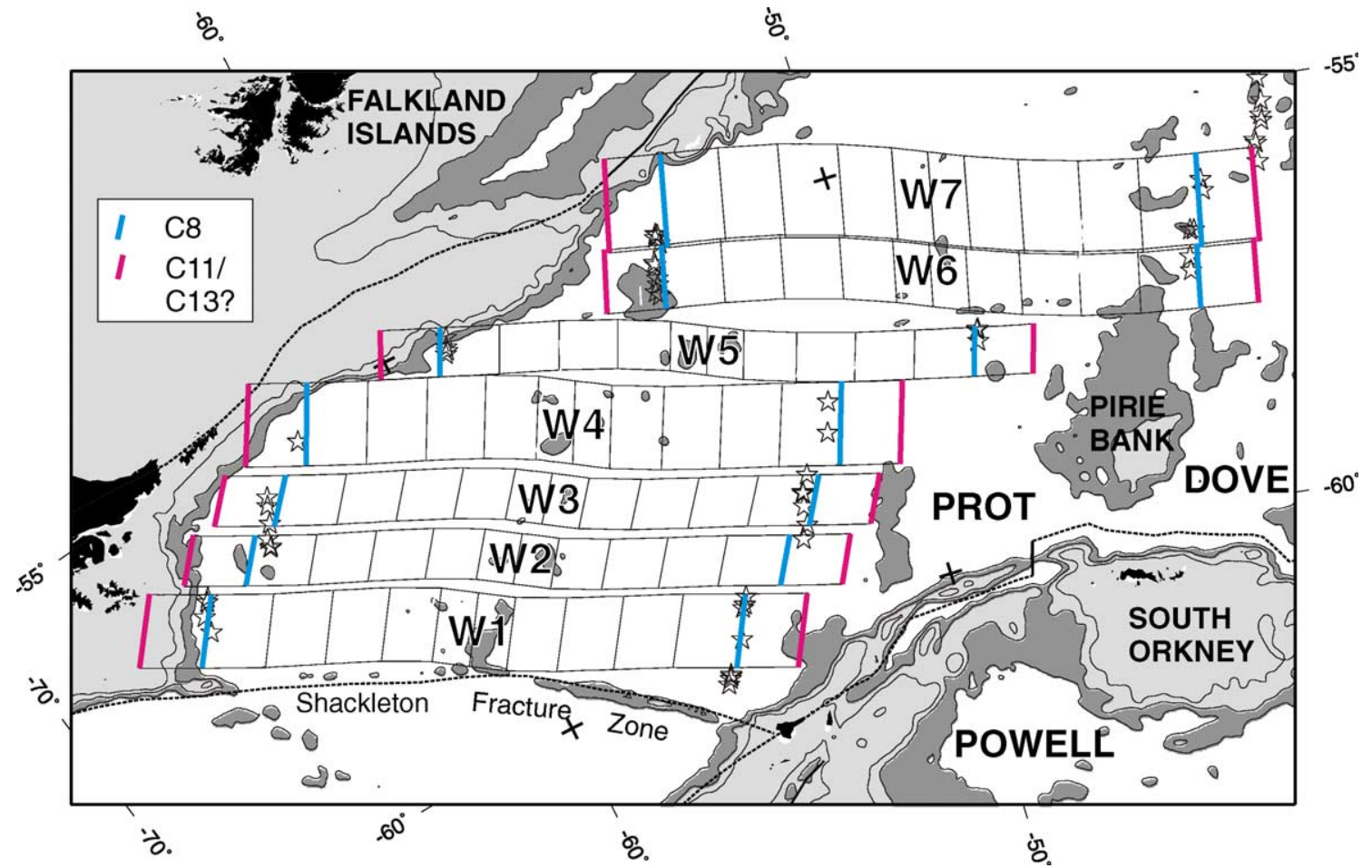

Fig. 6. Synthetic flow lines and isochrons in Drake Passage generated from the model of Eagles et al. [11] for West Scotia Ridge spreading. Magenta isochrons are extrapolated using earliest stage poles, and have an age of $30 \mathrm{Ma}$ (chron C11) if early rates are constant between break-up and C6B, but could be as old as $34 \mathrm{Ma}$ (chron C13) if initial rates were lower. Picks of magnetic anomaly C8 are shown as stars. PROTProtector Basin; DOVE_-Dove Basin; POWELL_Powell Basin. Projection is an oblique Mercator about a pole at $\left(17^{\circ} \mathrm{S}, 148^{\circ} \mathrm{E}\right)$.

7), and suggest that a major, deep, eastward current was already in existence soon after spreading began.

\section{Other evidence for Eocene opening}

Middle Eocene separation of South America from Antarctica should be detectable from the fossil record, since it involved breaking a terrestrial link between Tierra del Fuego and the Antarctic Peninsula, while permitting interchange of marine floras and faunas of the South Pacific and South Atlantic. Reguero et al. [27] noted that an endemic fauna, including several small marsupials, from the La Meseta Formation of Seymour Island, near the tip of the Antarctic Peninsula, was probably derived from the Late Paleocene land fauna of Patagonia, but became increasingly isolated during the Eocene. Our model supports their suggestion that this isola- tion was probably caused by the presence of a shallow and growing seaway, forming a physical barrier between the two populations.

Sijp and England [28] have recently reported results of coupled ocean-atmosphere-ice numerical modelling, which suggest that Drake Passage opening to shallow depths $(690 \mathrm{~m}$ in their model) could have a profound effect on sea surface temperatures in the Southern Ocean. If this is correct, then the gradual widening and deepening of the gateway may be connected with the gradual global cooling indicated by $\delta^{18} \mathrm{O}$ ratios [1], which also commenced at $\sim 50 \mathrm{Ma}$ (Fig. 7). However, other modellers [4,5] conclude that opening of Southern Ocean gateways alone could not have caused major changes in meridional heat transport, and show that abrupt cooling could have occurred as a result of a steady decline in atmospheric $\mathrm{CO}_{2}$. Nevertheless, even in this case, it is possible to contemplate a situation in which gateway opening, by increasing Southern 


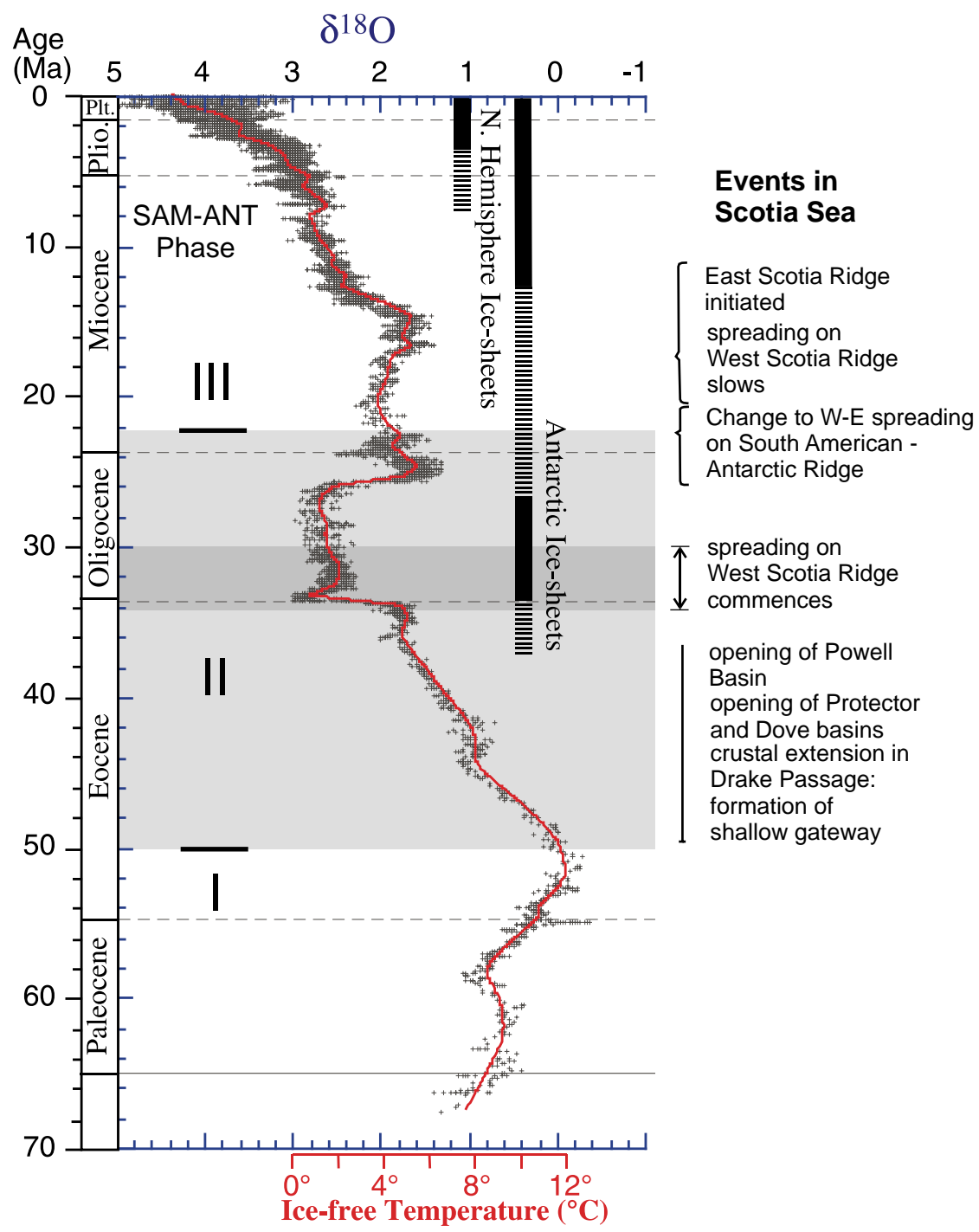

Fig. 7. Oxygen isotope ratios derived from benthic foraminera for the Cenozoic [5]. Phases of SAM-ANT motion derived here are shown on the left, correlations with events in and around Drake Passage are shown on the right.

Ocean upwelling and turnover, led to an increase in $\mathrm{C}$ sequestration and a consequent reduction in $p \mathrm{CO}_{2}$ [29].

Changes in deep-water circulation at about 32.8 Ma were suggested by Latimer and Fillipelli [30], based on geochemical proxies from ODP Site 1090 in the Agulhas Basin. A permanent change in the geochemical character of the terrigenous sediment fraction, together with a shift in clay mineralogy towards physically weathered material, were inter- preted as a result of Drake Passage opening at this time. Likewise, the termination of an 'opal pulse' together with a hiatus in sedimentation at about 32-33 Ma, in sediment cores from the same ODP site, is interpreted as evidence of Drake Passage opening to deep ACC flow [31]. While not conclusive, these results suggest not only that the gateway had opened, but that some form of proto-ACC had already commenced flowing by the earliest Oligocene. This, in turn, suggests that the formation of a 
deep-water pathway followed soon after spreading began at the West Scotia Ridge.

In summary, our kinematic model shows that a major, abrupt, change in SAM-ANT plate motion occurred in the middle Eocene $(\sim 50 \mathrm{Ma})$. The change required that the southern tip of South America began to migrate away from the Antarctic Peninsula at that time, yet the oldest sea floor within Drake Passage is unlikely to be older than 34-30 Ma. Hence, the relative motion must initially have been taken up by extension and thinning of continental crust, such as that which forms the southern tip of South America and the South Orkney microcontinent, and possibly by opening of minor basins in the southern Scotia Sea. This extension probably led to the formation of a region of submerged continental shelf, and established a shallow $(<1000 \mathrm{~m})$ connection between the Pacific and Atlantic oceans by the Middle Eocene.

\section{Acknowledgements}

Part of this work was completed under award GT4/93/233/G made by the Natural Environment Research Council. We thank two anonymous referees for valuable comments and suggestions, and Jim Zachos, for permission to use his compilation of $\delta^{18} \mathrm{O}$ data shown in Fig. 7.

\section{References}

[1] J. Zachos, M. Pagani, L. Sloan, E. Thomas, K. Billups, Trends, rhythms, and aberrations in global climate 65 Ma to present, Science 292 (2001) 686-693.

[2] J.P. Kennett, Cenozoic evolution of Antarctic glaciation, the circum-Antarctic ocean, and their impact on global paleoceanography, J. Geophys. Res. 82 (1977) 3843-3859.

[3] P.F. Barker, Scotia Sea regional tectonic evolution: implications for mantle flow and palaeocirculation, Earth-Sci. Rev. 55 (2001) 1-39.

[4] R.M. DeConto, D. Pollard, Rapid Cenozoic glaciation of Antarctica induced by declining atmospheric $\mathrm{CO}_{2}$, Nature 421 (2003) 245-249.

[5] M. Huber, H. Brinkhuis, C.E. Stickley, K. Doos, A. Sluijs, J. Warnaar, S.A. Schellenberg, G.L. Williams, Eocene circulation of the Southern Ocean: was Antarctica kept warm by subtrop- ical waters? Paleoceanography 19 (2004) PA4026, doi:10.1029/2004PA001014.

[6] L.A. Lawver, L.M. Gahagan, Evolution of Cenozoic seaways in the circum-Antarctic region, Palaeogeogr. Palaeoclimatol. Palaeoecol. 198 (2003) 11-37.

[7] M.E. Raymo, W.F. Ruddiman, Tectonic forcing of late Cenozoic climate, Nature 359 (1992) 117-122.

[8] P.F. Barker, J. Burrell, The opening of Drake passage, Mar. Geol. 25 (1977) 15-34.

[9] R. Livermore, G. Eagles, P. Morris, A. Maldonado, Shackleton Fracture Zone: no barrier to early circumpolar ocean circulation, Geology 32 (2004) 797-800.

[10] G. Eagles, R.A. Livermore, D. Fairhead, P. Morris, Tectonic evolution of the west Scotia Sea, J. Geophys. Res. 110 (2005) B02401, doi:10.1029/2004JB003154.

[11] E. Lodolo, F. Coren, A. Schreider, G. Ceccone, Geophysical evidence of a relict oceanic crust in the southwestern Scotia Sea, Mar. Geophys. Res. 19 (1997) 439-450.

[12] R.A. Livermore, R.W. Woollett, Sea-floor spreading in the Weddell Sea and Southwest Atlantic since the Late Cretaceous, Earth Planet. Sci. Lett. 117 (1993) 475-495.

[13] P.F. Barker, L.A. Lawver, South American-Antarctic plate motion over the past $50 \mathrm{Ma}$, and the evolution of the South American-Antarctic Ridge, Geophys. J. R. Astron. Soc. 94 (1988) 377-386.

[14] W.D. Cunningham, I.W.D. Dalziel, T.Y. Lee, L.A. Lawver, Southernmost South America Antarctic Peninsula relative plate motions since $84 \mathrm{Ma}$-implications for the Tectonic Evolution of the Scotia Arc Region, J. Geophys. Res. 100 (1995) 8257-8266.

[15] P.R. Shaw, S.C. Cande, High-resolution inversion for South Atlantic plate kinematics using joint altimeter and magnetic anomaly data, J. Geophys. Res. 95 (1990) 2625-2644.

[16] D.C. Engebretson, A. Cox, R.G. Gordon, Relative motions between oceanic plates of the Pacific Basin, J. Geophys. Res. 89 (1984) 291-310.

[17] A.P. Nankivell, Tectonic evolution of the Southern Ocean. PhD thesis, Oxford University (1997).

[18] D.T. Sandwell, W.H.F. Smith, Marine gravity anomaly from Geosat and ERS 1 satellite altimetry, J. Geophys. Res. 102 (1997) 10039-10054.

[19] R.A. Livermore, J.S. Tomlinson, R.W. Woollett, Unusual seafloor fabric near the Bullard Fracture-Zone imaged by Gloria Sidescan Sonar, Nature 353 (1991) 158-161.

[20] C. Demets, R.G. Gordon, D.F. Argus, S. Stein, Effect of recent revisions to the geomagnetic reversal time-scale on estimates of current plate motions, Geophys. Res. Lett. 21 (1994) 2191-2194.

[21] R.A. Livermore, Back-arc spreading and mantle flow in the East Scotia Sea, in: R.D. Larter, P.T. Leat (Eds.), IntraOceanic Subduction Systems and Magmatic Processes, Special Publications, vol. 219, Geological Society, London, 2003, pp. 315-331.

[22] P.L. Barber, P.F. Barker, R.J. Pankhurst, Dredged rocks from Powell Basin and the South Orkney microcontinent, in: M.R.A. Thomson, et al., (Eds.), Geological Evolution 
of Antarctica, Cambridge University Press, 1991, pp. $361-367$.

[23] B.H. Kirkwood, J.Y. Royer, T.C. Chang, R.G. Gordon, Statistical tools for estimating and combining finite rotations and their uncertainties, Geophys. J. Int. 137 (1999) $408-428$.

[24] A.A. Tikku, S.C. Cande, The oldest magnetic anomalies in the Australian-Antarctic Basin: are they isochrons? J. Geophys. Res. 104 (1999) 661-677.

[25] S. Levi, R. Riddihough, Why are marine magnetic-anomalies suppressed over sedimented spreading centers? Geology 14 (1986) 651-654.

[26] M.P. Meredith, J.L. Watkins, E.J. Murphy, P. Ward, D.G. Bone, S.E. Thorpe, S.A. Grant, R.S. Ladkin, Southern ACC front to the northeast of South Georgia: pathways, characteristics, and fluxes, J. Geophys. Res. 108 (2003) (art no.-3162)

[27] M.A. Reguero, S.A. Marenssi, S.N. Santillana, Antarctic Peninsula and South America (Patagonia) Paleogene terrestrial faunas and environments: biogeographic relationships, Palaeogeogr. Palaeocl. Palaeoecol. 179 (2002) 189-210.
[28] W.P. Sijp, M.H. England, Effect of the Drake Passage throughflow on global climate, J. Phys. Oceanogr. 34 (2004) 1254-1266.

[29] P.N. Pearson, M.R. Palmer, Atmospheric carbon dioxide concentrations over the past 60 million years, Nature 406 (2000) 695-699.

[30] J.C. Latimer, G.M. Filippelli, Eocene to Miocene terrigenous inputs and export production: geochemical evidence from ODP Leg 177, Site 1090, Palaeogeogr. Palaeoclim. Palaeoecol. 182 (2002) 151-164.

[31] B. Diekmann, G. Kuhn, R. Gersonde, A. Mackensen, Middle Eocene to early Miocene environmental changes in the subAntarctic Southern Ocean: evidence from biogenic and terrigenous depositional patterns at ODP Site 1090, Glob. Planet. Change 40 (2004) 295-313.

[32] A.V. Golynsky, P. Morris, R. von Frese and the ADMAP Group, BAS (Misc) 10, British Antarctic Survey, Cambridge, UK, 2001.

[33] S.C. Cande, D.V. Kent, Revised calibration of the geomagnetic polarity timescale for the late cretaceous and cenozoic, J. Geophys. Res. 100 (1995) 6093-6095. 